\title{
Retailers and planning gain: The rights and wrongs and what is to be done about them
}

Received (in revised form): 4 September 2003

\section{Stephen Crow}

is Honorary Professor of Planning Policy and Practice at the School of City and Regional Planning of Cardiff University. A former chief planning inspector for England and Wales, he has written and spoken extensively on the subject of planning gain, and firmly believes that reform of practice in this field is urgently required.
Abstract
After decades of argument, views about 'planning gain' are polarised into two camps: those who would set no limits other than practicability on what is obtained through planning gain - the 'get what you can' or 'taxation' camp - and the camp of strict rules about the provision of necessary infrastructure and the mitigation of development impacts etc - the 'logical nexus' camp. So polarised, there can be no logical halfway house, no 'third way'.
As both practitioner and academic observer, the author has observed the development of planning gain since first encountering it over 30 years ago. Although many planning officers, particularly in the past decade, have attempted to bring better order to their own practice, this has not been easy given the pressures in many authorities to maximise income from the negotiation of planning applications, the lack of acceptable advice from the centre and 'hands-off' court judgments in which retail developments have taken a high profile. As a result, much of the practice by which planning gain is obtained from developers is, in the opinion of many, including the 1997 Nolan Committee on Standards in Public Life, bad practice, violating the fundamental principle that planning permissions cannot be bought and sold. This is not merely a matter of personal opinion or anecdotal evidence, as is sometimes asserted. In fact, evidence of abuse has systematically been drawn together in a Royal Institute of Chartered Surveyors (RICS) research paper $^{1}$ which clearly indicates that the practice of planning gain has led to the subversion or abandonment of public service principles and values which ought to be inherent in the planning system.
At the end of 2001 the government published a series of consultation documents that included one on reforming planning obligations. This unfortunately attempted to live in both of the planning gain camps, driven to a large extent by its wishful thinking that increasing amounts of affordable housing

Professor Stephen Crow Department of City and Regional

Cardiff University

Glamorgan Building King Edward VII Avenue Cardiff $\mathrm{CF}_{10} 3 \mathrm{WA}$, UK

Tel: +44 (o)29 20876519 Fax: +44 (0) 2920874845 E-mail: crows@cardiff.ac.uk 
Generous gifts

\section{What do people want from the system?}

can be derived from planning gain. Not surprisingly, these proposals have pleased nobody and got nowhere.

If only the government had followed the advice of the Royal Town Planning Institute (RTPI), which in 2000 proposed a fair and systematic method based on the development plan and a firm, logical connection between the development proposed and the obligation sought.

Revision of government policy advice is long overdue, but is not likely to be enough. A change in the law is needed, but how can this be achieved without bringing the courts into questions of planning merits? Meanwhile, what is a retail developer to do when faced with plainly unjust demand for 'planning gain'?

\section{Keywords:}

planning gain, planning obligations, s. 106, development plan, infrastructure, 'logical nexus', abuse of process

\section{INTRODUCTION: THE TWO CAMPS - 'GET WHAT YOU CAN' AND 'LOGICAL NEXUS'}

Merchant adventurers in bygone centuries who wished to open a trading post on the coast of some hitherto unexplored continent found it expedient to offer generous gifts to the local chiefs. This was not of course great generosity; rather, without the gifts, the trading post just did not get opened.

Have things improved much in 21 st century Britain? If retailers do not offer local planning authorities generous gifts by way of planning gain they do not get to open their new stores. But is this all there is to it? This paper attempts to explain some of the rights and wrongs.

Readers will not be surprised to discover that the rights and wrongs of planning gain are fiercely argued among planners in the UK. Indeed, the arguments have been going on for decades, until today one finds views about 'planning gain' being polarised into two camps: those who would set no limits other than practicability on what is obtained through planning gain - the 'get what you can' or 'taxation' camp - and the camp of strict rules about the provision of necessary infrastructure and the mitigation of development impacts etc - the 'logical nexus' camp. It is true that both camps are to a large degree agreed in that both would like to see some greater order and transparency brought into the process by which planning gain is obtained. For example, there is little argument against matters which can be sensibly covered by condition being so covered, or for greater transparency being brought into the process, such as seeing that planning obligations are placed on the planning register. ${ }^{2}$

But in terms of the products of planning gain, that is what people want to get out of the system, what they see as legitimate products and what are not, opinions are polarised. They are 


\section{Law, policy and practice should fit together}

polarised to the extent that there can be no logical halfway house, no 'third way'.

In the first camp are those who see practice as 'receiving some benefit for accepting development in their areas' (to paraphrase the government's 2001 publication Reforming Planning Obligations ${ }^{3}$ ) and who would go in for the valuation of development projects in order better to understand what can be squeezed out of them. This group, like the House of Commons Select Committee, would see planning gain as a potential or informal taxation system. In the other camp are those who would follow the stricter line that was inherent in government policy for several decades, wanting to see a firm, logical connection between the development proposed and the obligation sought - what in the USA is called 'rational nexus'.

\section{PLANNING GAIN AND THE LAW}

How is it that there is so little agreement among practitioners on such an important matter? The answer lies in the law, or rather the lack of it in either statute law or court judgments. As a result, law, policy and practice, which ought to nest comfortably one within the other like Russian dolls, ${ }^{4}$ have become altogether out of joint, with the law saying one thing, policy almost the opposite and planners doing more or less what they like, in many cases adopting the 'get what you can' approach. But, in the progressive evolution and clarification of case law, readers will probably not be surprised to discover that retail developments have played a leading role.

From the earliest days planning law in the UK has made provision for the making of legally binding agreements between local planning authorities and landowners and others with an interest in land. The current situation is that anyone with a legal interest in land can enter into a 'planning obligation' made under s. 106 of the Town and Country Planning Act 1990 (TCPA 1990). ${ }^{5}$ The obligation may be made by agreement with a local planning authority, or may be a unilateral undertaking made by the developer alone.

Increasingly since the early 1970 s the practice has grown up for local planning authorities to require developers to undertake a very wide range of works necessary for the success of the proposed development. At its simplest, this could be a requirement for an improved road junction, or for environmental mitigation such as a replacement wildlife habitat. More controversially, the requirement could be for a cash contribution for social infrastructure that may or may not have some direct or obvious connection with the development proposed. Unless developers either comply with what is required or negotiate a more favourable (for them) agreement, they risk not gaining the grant of planning permission for their proposed development, or at least face considerable delay in an appeal. ${ }^{6}$

By and large, the courts have not attempted to restrict this growing practice. Back in 1989, the High Court determined that the 
test of a fair and reasonable relationship to the development proposed did not apply to the making of statutory planning agreements, unlike the imposition of a condition on a planning permission.

Two years later retailing entered the legal scene, in the shape of the Safeway case. ${ }^{7}$ In this case, the Court of Appeal quashed a decision by the Secretary of State to refuse outline planning permission for a superstore, petrol filling station and ancillary development. The flaw in the Secretary of State's decision, said the Court of Appeal, was that the inspector who had conducted the inquiry into the appeal had wrongly excluded an offer of planning gain from his consideration. The offer was that the developers would provide financial assistance for the implementation of traffic management measures which, it was claimed, would go some way to alleviate the effects of increased traffic in the vicinity of the site and would benefit the already overcrowded traffic system in the locality generally. But the court in this case did not take the opportunity to clarify the legal uncertainty over the precise relationships between the determination of applications for planning permission and planning gain. Instead, it concerned itself merely with the correctness of the interpretation given by an inspector to current government policy. ${ }^{8}$ In interpreting policy, the Court of Appeal held that there were insufficient reasons for the inspector to conclude that the measures to be financed by Safeway were not so directly related to the proposed development of the site that the superstore ought not to be permitted without them.

If this judgment left the law in doubt, it was clarified in another retailing case, the Plymco ${ }^{9}$ case. The background to this case was that Plymouth City Council had been advised by its planning officers that only one permission should be granted for a superstore on the eastern approach to Plymouth. The council thereupon organised a competition. They invited prospective developers to select from a menu of 'community benefits', all of which satisfied the test of being fairly related to the proposed development, and indicated that it would take into account the extent to which a developer would be willing to pay for items on the menu. Having received two attractive bids which included a number of external benefits, the council changed its mind and decided to grant both permissions. This was challenged by the local cooperative society, which had a competing supermarket nearby, on the grounds that the local planning authority had taken into account an offer of benefits which were not necessary, in the sense that they overcame what would otherwise have been planning objections to the development, and so were not material to the decision.

But the Court of Appeal dismissed the appeal on the grounds that the test of necessity was not a legal requirement. They said this because to impose such a test as a matter of law, rather than of policy or good practice, would cut across the professional and administrative judgment of local planning authorities and their 
Planning judgment and the law advisers. These are matters which the courts in the UK have resolutely avoided (unlike those in the USA, which are necessarily concerned with the constitutional propriety of the 'taking' of property by public authorities). So in considering a development application, a local planning authority can take account of a planning agreement just so long as its contents are not outside what the courts in 50 years of case law have ruled to be material considerations ${ }^{10}$ and also:

- serve a planning purpose

- are fairly and reasonably related to the development permitted

- the decision is not so 'unreasonable that no reasonable public body would have made it ${ }^{11}$ (to use a term well known to administrative lawyers).

Not long afterwards, Tesco wanted to build a new store at Witney in Oxfordshire, encouraged by the remarks of the inspector who had earlier heard objections to a draft roll forward of the local plan. There was a big snag: Witney is divided in two by the River Windrush, traffic congestion is bad at the one river crossing in the town and the superstore would have made it somewhat worse. There was a plan for a second bridge and a connecting link road, but no funding. So Tesco, quite reasonably as they thought, offered to pay for the bridge and the link road. The inspector conducting an inquiry into Tesco's planning application agreed, but not the Secretary of State, whose decision it was.

True, suggested the Secretary of State, the offer related to something that was necessary, in the sense that without it the application would necessarily have been refused. But the bridge and the road would have served a much wider area and would have yielded many more public benefits than just opening up the site for the superstore. The offer was out of all proportion to the need, and so the Secretary of State, following his own policy (about which more later), attached little weight to it and refused permission. Tesco took the Secretary of State to court on the basis that the tests of necessity and proportionality were not matters of law and so should not have been applied to their application. The Tesco case was eventually thrown out by the House of Lords on the basis that the Secretary of State is entitled to apply his own policy and apply whatever weight he chooses to the material considerations. ${ }^{12}$ What one of the Law Lords, Lord Hoffman, said on this occasion is worth remembering:

'The law has always made a clear distinction between the question of whether something is a material consideration and the weight it should be given. The former is a question of law and the latter is a question of planning judgment, which is entirely a matter for the planning authority ... The distinction between whether something is a material consideration and the weight which it should be given is only one aspect of a fundamental 
Lincoln Coop

Government policy principle of British planning law, namely that the courts are concerned only with the legality of the decision-making process and not with the merits of the decision. If there is one principle of planning law more firmly settled than any other, it is that matters of planning judgment are within the exclusive province of the local planning authority or the Secretary of State.'

In short, the 'get what you can' approach evident at Plymco may not necessarily be unlawful, but those wanting to follow a stricter line are also entitled to do so. Tesco also provided the opportunity for one of the Court of Appeal judges (Lord Steyn) to remind people (apropos Plymco) of the fundamental principle that planning permissions must not be bought and sold, still less, as Lord Hoffman in the House of Lords commented in respect of the same case, put to 'auction'. ${ }^{13}$ That the law is not wholly open ended has more recently been demonstrated in the Lincoln Coop case. ${ }^{14}$ Here, the reversal of a previous refusal of permission for a superstore arising from a better offer of planning gain was held by the court to be Wednesbury unreasonable. ${ }^{15}$

It is always unwise to engage in legal speculation, but it could be that the dust has yet to settle on case law in this field.

\section{POLICY ON A DIFFERENT ROAD}

Despite the laissez-faire attitude of the courts, there have been years of official attempts (largely unsuccessful) to keep a tight rein on practice. In 1981 the Department of the Environment's Property Advisory Group advised that 'as a matter of general practice, planning gain has no place in our system of development control'. ${ }^{16}$ Departmental Circular $22 / 83^{17}$ and later Circular $16 / 91^{18}$ developed this general line of policy. Although it may be argued that to some extent developments in policy have followed practice, government policy for years has remained rooted in what is now described as the test of necessity, expressed in the earlier circular as:

'It is a matter of law as well as of good administration that planning applications should be considered on their merits having regard to the development plan and other material considerations ... By the same token, the question of imposing a condition or obligation ... should arise only where it is considered that it would not be reasonable to grant a permission in the terms sought which is not subject to such condition or obligation. A wholly unacceptable development should not of course be permitted just because of extraneous benefits offered by the developer.' (emphasis added) ${ }^{19}$

The circular went on to offer four tests of reasonableness based on this general policy, and then added another, the test of proportionality, the application of which as a matter of policy was ten years later to be tested in the courts. 
Negotiation

\section{Standards in Public Life}

\section{... a further test has to be applied. This is whether the scale of what is required or sought is fairly and reasonably related in scale and kind to the proposed development. ${ }^{20}$}

This test, it will be recalled, is the one which wrecked Tesco's proposal at Witney.

The upshot of the interpretation of the primary legislation by the courts has been that local planning authorities have no particular reason to follow government policy. As a result, it is now widely accepted that planning obligations are being used by some local authorities to provide benefits or contributions that have minimal connection to the developments to which they are supposed directly to relate.

Is it not too much to describe the present situation as a nasty mess?

\section{THE MACHINERY OF PLANNING GAIN}

The initiative for the making of an agreement may come from either the local planning authority or the developer, but almost inevitably the immediate result of an initiative is a period of negotiation between the parties. Neither side holds all the cards: the local planning authority may negotiate on the basis that its demands are a necessary precondition of planning permission, but in fact they are constrained both by lack of knowledge of the likely profitability of the proposed development and by the threat of appeal. Needless to say, some local planning authority officers are better at negotiation than others (and may be more knowledgable or 'wise' in terms of property valuation), while some authorities are more scrupulous than others in imposing policy limits on their demands.

The extent of planning gain arrangements may be judged from a recent survey ${ }^{21}$ which showed that permissions for 17.6 per cent of major developments in England were linked to planning obligations. It should also be noted, however, that most planning applications are made for quite small developments which in most cases escape from the planning gain net. So of all planning permissions granted only 1.5 per cent are linked to s. 106 obligations.

\section{PRACTICE, GOOD AND BAD}

Not all planning authorities of course flagrantly disregard the advice of the Department of the Environment Circular 16/91. But many do, and the evidence of serious abuse of the planning process is not all anecdotal.

In 1997 the Committee on Standards in Public Life (the Nolan Committee) found the practice of planning gain to be 'the most intractable aspect of the planning system with which [they] had to deal'. They identified three common criticisms which had 'a tremendous impact on public confidence': that planning permissions 
were being bought and sold, that developers were being held to ransom by local authorities and that the detail of negotiations between local authorities and developers was covered by a cloak of commercial confidentiality, leading to charges of impropriety. The committee recognised the validity of all of these criticisms ${ }^{22}$.

Although for many years evidence of abuse, although widespread, was largely anecdotal, it has recently been systematically surveyed and the findings drawn together in a RICS research paper. ${ }^{23}$ This paper, after reviewing an abundance of survey material, convincingly concludes that the practice of planning gain has led to the subversion or abandonment of values which ought to be inherent in the planning system. ${ }^{24}$

Moreover, the negotiation of planning gain itself takes time and is a potent source of delay. A Department of the Environment (DOE) sponsored research report recorded in 1995 that 80 per cent of cases involving the completion of an s. 106 agreement took 12 months or more in determination. ${ }^{25}$ Another such study, this time of major projects only, found an average of 13 months to conclude agreements, with this activity occupying no less than 44 per cent of the total project timescale. ${ }^{26}$

Since every agreement or obligation is individually negotiated and has to be the subject of a formal legal document, the process is expensive in legal costs. Nor is there adequate financial accountability. At the present time there is no systematic way in which accounts relating to planning gain are kept, with the result that contributions are not necessarily being used for the purposes for which they were originally sought. Nor is there any systematic provision for the refunding of payments if the infrastructure paid for is not actually constructed.

It is true that since Lord Nolan made his criticisms of the system in 1997 some planning authorities and their officers have tried to bring some rationality and order to the subject. But the evidence is that a minority only have done so. ${ }^{27}$ Most prefer to carry on regardless. So it is not surprising that many outside the ranks of planning officers and councillors share the view of John Gummer that 'planning gain is the nearest thing we have to institutionalised corruption'. ${ }^{28}$

There is possibly a human rights aspect to the issues. The UK's

\section{Human rights} Human Rights Act 1998 brought the European Convention on Human Rights (ECHR) into domestic law, enforceable by the courts of the UK. Article 1 of the First Protocol to the ECHR is about the protection of property rights, although it does not give an absolute protection, as laws may be made 'to control the use of property in accordance with the general interest or to secure the payment of taxes or other contributions or penalties'. ${ }^{29}$ The Constitution of the USA covers much the same sort of ground in requiring fair compensation for the 'taking' of property. One must be clear that, in making obligations necessary prerequisites of planning permissions, planners have left behind the fiction of 


\section{Reforming the system}

voluntarism and are establishing requirements. As regards planning requirements, the UK might usefully bear in mind the US Supreme Court cases of Nollan and Dolan ${ }^{30}$ and consider carefully whether planning requirements that take away from the value of property might be unlawful unless they bear some sort of reasonable proportionality to the development proposed. Whether the government is conscious of this issue is unknown. The Atlantic has little effective width these days.

So what is to be done?

\section{THE DTLR CONSULTATION DOCUMENT}

Nearly two years ago, the UK government published a series of consultation papers on planning, including one entitled Reforming Planning Obligations. ${ }^{31}$ In essence, this paper attempted a more structured approach to the use of planning obligations based on a form of a standard tariff set locally through the local plan process. This would only be varied by a negotiated element where this was necessary to address the particular circumstances of a development.

The paper went on to say that national guidance would be issued about the workings of the new tariff-based system. This would require local authorities to set clear policies in their plans about their use of planning obligations and their approach to setting tariff schedules. It would also set out the requirements for local authorities to operate the system in an efficient way - including use of standardised terms in agreements and proposals for monitoring and accounting. The guidance would give local authorities discretion about their approach to the use of planning obligations within the overall framework set at national level.

The driver of much in Reforming Planning Obligations was plainly the desire of the government to secure more affordable housing through the planning process. ${ }^{32}$ Historically, housing and planning legislation grew up together as a reaction to the appalling housing conditions for working people in the late Victorian era. Today planning has a number of important tasks in this context, apart from seeing that enough homes are created through house building, conversions and bringing unnecessarily empty property back into use. Just as important, planning needs to ensure that the right sort of homes are created, having regard to market, demography and social and economic needs. This principle will always necessitate mixed towns and neighbourhoods and within them mixed developments in which homes are created for the less well-to-do, and in which rich and poor (and those in between) can co-reside to the benefit of all. But an all-too-plain objective in Reforming Planning Obligations was that commercial housing development should subsidise affordable housing. This, of course, is a much more controversial issue.

Not surprisingly, given the polarisation of views on the subject, the proposals of Reforming Planning Obligations have been both acclaimed as a 'tax on development value' but also attacked as a 
Support for the Government line

\section{Criticisms}

'tax on development'. It all depends on which camp commentators find themselves in.

In support of the 'get what you can' camp, the House of Commons Select Committee on Transport, Local Government and the Regions, having heard a wide range of evidence on Reforming Planning Obligations, noted that 'the source of funds which will pay a tariff is assumed by Government to be the increase in land value which arises when planning permission is given for a higher value use. Tariffs are therefore a tax on development value. ${ }^{33}$ But the Select Committee then questioned whether the proposed tariff system would in fact raise more money than the current system of negotiation. ${ }^{34}$

As a tax, the tariff proposal angered the House Builders Federation, which called it 'little more than a tax on development which will depress the market, damaging continued economic growth and stifling much needed housing development', and they called for the link between the development and any planning obligations sought to be retained rather than for all developments to make a contribution towards a general 'community chest'. ${ }^{35} \mathrm{~A}$ similar comment has been made by John Gummer MP ${ }^{36}$ while the Confederation of British Industry (CBI) has described the proposals as 'nothing less than a stealth tax on regeneration and a major obstacle to companies that want to help councils create wealth and jobs. ${ }^{37}$

In a more measured response to the consultation, the Royal Town Planning Institute (RTPI) reminded the government that planning obligations ought to be environmental measures, not fiscal ones. The proposed tariffs should not be seen as a form of local tax collection (indeed they would not be if planning obligations were used only to make a deficient proposal acceptable), but a means to provide necessary infrastructure or to overcome an environmental problem which may be caused by the proposal. Local planning authorities should not use planning obligation negotiations to impose an unreasonable burden on developers, especially to the point that they deter the development by making it uneconomical. ${ }^{38}$

If only the government had followed the advice of the RTPI, which earlier had proposed a fair and systematic method based on the development plan of using planning gain to provide all necessary infrastructure and mitigate environmental damage. In putting forward its proposals, the RTPI paper ${ }^{39}$ had four objectives in mind:

- securing balanced, well-planned development

- ensuring transparency of process

- securing equity between all taking part

- speeding up the process. 


\section{The Royal Town Planning Institute}

stole the title for their own flawed proposals - but not all the RTPI's ideas.

In a nutshell, the RTPI's idea of a tariff approach was that the development plan would set out the basic policy for the tariff, and then go on, with the help of supplementary planning guidance wherever necessary, to establish on an area-by-area basis the requirements for physical and social infrastructure, environmental mitigation and so on.

Emphasis was placed on the integration of proposals for planning gain with other development plan proposals, for the reason that the development plan and other elements of the forward planning process are the places where the public has a legitimate expectation of finding the governing criteria as to what is, and what is not, well-planned development. There would then be a fair and transparent means of assessment, by which the necessary facilities would be paid for by developers unless they were actually physically provided in the development proposed.

Where more than one developer was involved, or perhaps even many small developments were involved, there would have to be a fair and transparent means of apportionment, preferably decided on a national basis. Apportionment by reference to gain in land values was not recommended by the RTPI, despite its theoretical attraction, because of the uncertainties involved. Better would be a 'per house' or 'per square metre' sort of apportionment. Then of course there would need to be proper accounting, in which it was clear that money paid would be refunded if the subject of the tariff did not proceed within a given period.

All this, it has been argued, is the stuff of North American impact fees, in which a fee may be charged on development which has to be 'roughly proportionate to the development's impacts' ${ }^{40}$ The main difference, however, is that the RTPI proposal avoids the inflexibility of the impact fee system by permitting the flexibility of negotiation in unusual or difficult cases. The inflexibility of impact fees would bear particularly hard on difficult but highly desirable developments, and could be a fatal burden on development in areas of slack development pressure. So considerable flexibility is necessary. The RTPI paper proposed that, where there needed to be negotiations, they should take place before the making of a formal application.

In short the RTPI suggested a locally based tariff system that clearly related the product of the tariff to the development proposed, and was directed to securing good planning rather than collecting revenue. Something on these lines is not only still desirable, but necessary if the drive to raise cash by any means is not to push planning into increasing disrepute.

\section{A CHANGE IN THE LAW?}

The problem quite simply is that without any form of sanction, legal or otherwise, many councils see no reason to comply with 
Is there a way out?

\section{And what should we do?}

policy requiring them to take a stricter line. So should the law be changed?

One way that it should not be changed is to reverse the outcome of the Plymco case so as to prevent local planning authorities in deciding a planning application from taking into consideration a planning obligation going outside the twin tests of necessity and proportionality, so as to enable the courts to quash a planning permission if they did. That would open up the field too much for third-party challenges to permissions by jealous competitors and, as Lord Hoffman pointed out, bring the courts into undesirable consideration of planning merits.

Yet the courts are involved in the application of similar tests ${ }^{41}$ if they are ever required to consider the validity of a condition. The difference is less one of the law itself, but rather of procedure. Complaints to the court about conditions come less from third parties than from disgruntled applicants or appellants.

What would appear sensible therefore is that a planning obligation made in respect of the grant of permission should be valid only if the planning obligation itself complied with tests of necessity and rough proportionality. Local authorities would then be on their guard not to negotiate an agreement that could subsequently be deemed invalid. They would have to be, as it were, on their best behaviour. Perhaps this is something for the lawyers to mull over, if they have not already done so.

\section{PLANNING GAIN AND THE RETAIL DEVELOPER}

Meanwhile, what are retail developers supposed to do when faced with demands that they regard as exorbitant? For a retail developer, as with any other, there are three options.

The first option is to appeal to the Secretary of State, on the grounds that the demands for planning gain exceed anything that is either necessary or proportionate. Then, if one has a good case in other respects and the proposal accords with the policy of PPG6 ${ }^{42}$ and its manifold 'clarifications' (but that is another story), the Secretary of State will determine the proposal having regard to the policy of Circular 16/91. ${ }^{43}$ But the appeal will take time (currently 80 per cent of inquiry decisions are made within 101 weeks $\left.{ }^{44}\right)$. Can one afford to wait so long?

Or, if a developer thought that the planning authority was engaged in the buying and selling of planning permissions, they could seek legal advice as to whether it was worth a groundbreaking legal challenge based on the sayings of Lords Steyn and Hoffman. That course would probably take even longer, and the outcome would be highly speculative. Perhaps somebody will try that one on sometime, but why a particular developer?

Or one could just pay up, if one can afford to, and get on with the job. (But can one afford not to?) Delay costs money. At least, unlike the merchant adventurers of old, the developer will live to see another day, whatever course they decide upon. 


\section{References and Notes}

1. Campbell, C., Ellis, H., Hennberry, J., Poxon, J. and Rowley, S. (2001) 'Planning obligations and the mediation of development', RICS Foundation Research Paper, Vol. 4, see www.rics-foundation.org/publish./

2. The Town and Country Planning (Development Procedures) Amendment Order 2002, see www.hmso.gov.uk.

3. DTLR (2001) Reforming Planning Obligations: Delivering a Fundamental Change, DTLR, December.

4. A vivid analogy coined by Peter Wilbraham many years ago: Wilbraham, P. (1995) Town and Country Planning Summer School Proceedings, p. 55.

5. This Act of Parliament applies to England and Wales only, but similar legislation is in place in Scotland and Northern Ireland. Future references are to the England and Wales legislation only. 'Planning obligations' are often called 'planning agreements', which was their proper name until amendments were made to the 1990 Act in 1991.

6. The legislative provisions are s. 70(2) and s. 54A of the Town and Country Planning Act 1990. Section 70 (2) requires the determination of an application for planning permission to 'have regard to the provisions of the development plan, so far as material to the application, and to any other material considerations'. Section $54 \mathrm{~A}$ says that ' $\ldots$ the determination shall be made in accordance with the plan unless material considerations indicate otherwise'.

7. Safeway Properties Ltd v Secretary of State for the Environment [1991] JPL 966.

8. DoE Circular 22/83, Planning Agreements, see hmso.gov.uk/.

9. R. v Plymouth City Council (ex parte Plymouth and South Devon Cooperative Society) (1993) 67 P [1993] JPL 1099.

10. That is in broad terms not irrelevant to the development, or serving an ulterior purpose.

11. Known to lawyers as the 'Wednesbury' test from Associated Provincial Picture Houses v Wednesbury Corporation [1948] 1 KB 223, etc in which the Court laid down the law that a decision of a public body must not be so unreasonable that no reasonable public body would have made it; that is - irrational.

12. Tesco Stores Ltd v Secretary of State for the Environment [1995] 2 All ER 636 [1995] JPL 581.

13. Supra [1995] JPL at p. 600.

14. R. v South Holland District Council, ex parte Lincoln Cooperative Society Ltd. [2001] JPL 675.

15. See ref. 11 above.

16. Property Advisory Group (1981) HMSO, London.

17. Department of the Environment (1983) 'Planning agreements', Department Circular 22/83, HMSO, London.

18. Department of the Environment (1991) Planning obligations', Department Circular 16/91, HMSO, London.

19. Department of the Environment, ref. 17 above.

20. The Rt. Hon. Lord Nolan (1997) The Third Report of the Committee on Standards in Public Life, Cm 3702-1, Stationery Office, London.

21. Campbell et al., ref. 1 above.

22. Committee on Standards in Public Life (the Nolan Committee) paragraphs $302 \mathrm{f}$ and $307 \mathrm{ff}$.

23. Campbell et al., ref. 1 above.

24. Ibid.

25. Grimley J. R. Eve with Thames Polytechnic and Alsop Wilkinson (1992) The Use of Planning Agreements, Department of the Environment Research Report, HMSO, London, p. 8.

26. C. R. Planning and N. Nathanson (1993) Development Control and the Timescale of the Development Process, Department of the Environment, London. See also Roger Tym and Partners (1989) The Incidence and Effects of Planning Delays, House Builders Federation, London, see www.new-homes.co.uk./ 
27. Campbell et al., ref. 1 above, p. 17.

28. Gummer, J. (2002) 'Planning gains, property rights and corruption', Planning, 1 February.

29. European Convention on Human Rights, available at www.echr.coe.int/Eng/ Basictexts.htm

30. Nollan v California Coastal Commission (1987) 483 US 825, also Dolan v City of Tigard, $114 \mathrm{~S} \mathrm{Ct} 2309$. It was these cases, among others, that led US lawyers to devise the principles of 'rational nexus' and 'rough proportionality'.

31. DTLR, ref. 3 above.

32. Ibid., see paragraph 4.19 - 'the affordable housing element may represent a large proportion of the overall tariff'.

33. House of Commons Select Committee on Transport, Local Government and the Regions (2002) Thirteenth Report of Session 2001-2002 on the Planning Green Paper, Volume 1: Report and Proceedings of the Committee, 3 July, The Stationery Office, London, paragraph 128.

34. Ibid, paragraph 131.

35. HBF Press Release, 19 March 2002, found at www.mew-homes.co.uk.

36. Gummer, ref. 28 above.

37. CBI Director-General Digby Jones reported in Planning, 22 March, 2002, p. 2.

38. Royal Town Planning Institute (2002) Press Release, 24 April PR2002/29, found at www.rtpi.org.uk./

39. The Royal Town Planning Institute (2000) Planning Gains and Obligations: A Policy Paper, London, December.

40. As might be expected, there is an extensive literature on impact fees. Beginners in the UK might try Callies, D. L. and Grant, M. (1991) 'Paying for growth and planning gain - An Anglo-American comparison of development conditions, impact fees and development agreements', The Urban Lawyer, Vol. 23, No. 2.

41. The 'Newbury' tests, from Newbury District Council v Secretary of State for the Environment [1981] AC 578.

42. Department of the Environment (1996) Planning Policy Guidance Note 6 'Town Centres and Retail Development' DoE, June, found at www.odpm.gov.uk/.

43. Department Circular 16/91, ref. 18 above.

44. Planning Inspectorate Statistical Report for 2001-2002 found at www.planninginspectorate.gov.uk, accessed 9 August 2003. 